\title{
PENGUATAN PENDIDIKAN KARAKTER DI ERA PANDEMI BERBANTUAN VIDEO MOTIVASI
}

\author{
SITI NURDJANAH \\ SMPN 40 Semarang \\ e-mail: nurjanahsiti296@gmail.com
}

\begin{abstract}
ABSTRAK
Penguatan pendidikan karakter di era pandemi covid-19 menemui banyak hambatan. Pemberlakuan sosial distancing ternyata berdampak pada keberlangsungan program pembinaan karakter siswa. Karena kebijakan pembelajaran daring maka diperlukan media yang cocok untuk menyampaikan materi karakter kepada siswa.Salah satu media yang bisa dimanfaatkan adalah video motivasi.Penggunaan video motivasi ini diharapkan mampu menyampaiakn materi karakter agar dapat diterima, dipahami, diinternalisasi sehingga karakter siswa terbina dengan baik.
\end{abstract}

Kata Kunci: Pendidikan,Karakter,video motivasi

\section{PENDAHULUAN}

Penguatan Pendidikan Karakter (PPK) sebagaimana diatur dalam Peraturan Presiden No 87 tahun 2017, mengalami banyak tantangan.Ragam kegiatan pembinaan karakter seperti pembentukan tata tertib sekolah, literasi,pembiasaan, dan ekstra kurikuler mengalami hambatan pelaksanaannya selama pandemi. Regulasi Kemdikbud tentang PPK dituangkan dalam Permendikbud No 18 tahun 2018. Ada 3 prinsip disebutkan dalam pelaksanaan penguatan karakter di sekolah pertama dilaksanakan dengan berorientasi pada perkembangan potensi peserta didik, kedua dilaksanakan dengan keteladanan di lingkungan pendidikan,serta ketiga dilaksanakan melalui pembiasaan sepanjang waktu dalam kehidupan sehari-hari.Sehubungan dengan pemberlakuan pembelajaran jarak jauh maka ketiga prinsip tersebut pun sulit untuk dilaksanakan. Menghadapi kondisi sulitnya menjalankan penguatan karakter di masa pandemi ,penulis tertarik untuk menggunakan video motivasi sebagai media penyalur materi karakter kepada siswa. Dengan memanfaatkan video motivasi dalam pembelajaran diharapkan aspek karakter dapat diinternalisasikan sehingga karakter siswa tetap terbina secara optimal.

Arti penting penelitian ini adalah untuk memberi kontribusi positif bagi upaya mengatasi lemahnya layanan pendidikan karakter di era pandemi.Sedangkan manfaat yang bisa diproleh dari penelitian ini ada tiga hal.Pertama bagi guru; dapat memperoleh pengalaman memperbaiki kualitas layanan penguatan karakter dengan memanfaatkan video motivasi.Kedua bagi siswa ; dapat merasakan dan mengalami layanan pendidikan karakter dengan media video motivasi.Ketiga bagi institusi/lembaga ;adalah memberikan kontribusi peningkatan mutu layanan pendidikan karakter yang lebih berkualitas.

Video motivasi dipilih sebagai media penguatan karakter karena selaras dengan pendapat Sadiman yang menyatakan bahwa video sebagai audio visual gerak mampu menyampaikan beragam materi baik berupa fakta, fiktif, informatif, edukatif maupun instruksional (Sadiman,2010:74). Sehubungan dengan penggunaan video motivasi, penulis sependapat dengan pernyataan Dwyer yang dikutip dalam skripsi Widya Ari Kusumadani yang menjelaskan bahwa video mampu merebut 94\% saluran masuknya pesan ke dalam jiwa manusia melalui mata dan telinga serta mampu untuk membuat orang mampu mengingat $50 \%$ dari apa yang mereka lihat dan dengar. Pesan melalui video dapat mempengaruhi emosi yang kuat dan dapat mencapai hasil yang cepat (Widya Ary Kusumadani, 2017:34)

\section{METODE PELAKSANAAN}

Kegiatan Best Practice ini dilaksanakan selama 3 bulan yaitu bulan September, Oktober dan Nopember tahun 2020.Tempat kegiatan di SMPN 40 Semarang.sasarannya adalah kelas IX-A SMPN 40 Semarang yang beranggota 32 siswa terdiri dari 17 siswa permpuan dan 15 
siswa laki-laki. Bentuk kegiatan adalah pembelajaran di kelas virtual google class room dengan media video motivasi sebagai saluran penyampai materi karakter.Aplikasi digital yang digunakan sebagai pendukung terdiri dari aplikasi google class room,wa grup,link (tugas kuis dan ulangan harian).

Materi pelajaran aspek pengetahuan yang disampaikan adalah dinamika pelaksanaan Pancasila dasar negara dan pandangan hidup bangsa, hakikat,macam dan teori kedaulatan dan lembaga kehakiman RI (MA,MK,KY). Media yang digunakan adalah power poit ataupun pwer point yang diexport menjadi video dengan teknik rekam layar.Selain itu diambilkan pula video you tube sesuai dengan materi yang dipelajari. Terkait aspek sikap, sarana yang dipakai adalah video motivasi Merry Riana.Alasan pemilihan video Merry Riana , adalah karena siswa sudah familiar dengan tokoh motivator tersebut.Selain itu Merry Riana sudah sering tampil dalam acara talk show di televisi.Adapun tema yang dipilih adalah yang digemari anak usia remaja.

Teknis pembelajaran yang dilakukan di google class room adalah dimulai kegiatan pendahuluan di bagian awal google class room, berupa salam pembuka dan himbauan untuk tetap bersemangat serta terus menjaga diri dan keluarga dengan menerapkan stándar prokes.Setelah itu dijelaskan langkah-langkah kegiatan yang harus dilakukan siswa dalam kegiatan belajar.Berikutnya di bagian bawah sebelah kiri fórum google class room dilampirkan video motivasi dari Merry Riana.Penyiapan video motivasi dilakukan sebelum pembelajaran berlangsung.Penulis mengunduh beberapa video sekaligus lalu dipilih untuk disematkan di bagian awal google class room setiap kali pembelajaran berlangsung.

Kegiatan dilanjutkan dengan pemberian materi pembelajaran di bagian materi,serta pemberian tugas di menú tugas siswa.Tugas bisa berupa tugas terstruktur berupa produk atau proyek bisa juga berupa tugas kuis (soal).Jika dibuat soal menggunakan google form, maka langsung dilengkapi link agar siswa bisa mengaksesnya.

Metode yang digunakan dalam pelaksanaan best practice ini adalah observasi dan wawancara.Observasi dilakukan untuk mendapatkan data tentang frekuensi penggunaan kata non santun siswa serta untuk mengumpulkan data mengenai kualitas pembelajaran yang dilaksanakan.Instrumen observasi menggunakan lembar pengamatan dengan format yang disusun sesuai indikator yang akan diamati. Kegiatan akhir pembelajaran adalah penutup.Kegiatan guru adalah melakukan proses rekap data tugas dari siswa baik berupa tugas terstruktur maupun tugas kuis.Jika tugas terstruktur guru bertugas memberi skor lalu mengembalikannya kepada siswa ditambah dengan chat komentar yang sesuai.Jika tugas kuis maka guru menganalisis respon pada spreed sheet kemudian memilah data berdasarkan kelas, diurutkan sesuai nomor absen lalu dimasukkan ke dalam daftar nilai kelas

Pada kegiatan ini,aplikasi wa grup digunakan sebagai sarana komunikasi guru dan siswa,juga komunikasi siswa dengan siswa.Ruang wa grup ini pun dipakai sebagai lokasi pengamatan penggunaan kata-kata non santun oleh siswa pada saat berkomunikasi.Sebagai bukti fisik penulis membuatkan screen shot dari percakapan tsb kemudian direkap untuk mendapatkan jumlah kata-kata non santun dalam periode bulanan dan mingguan. Instrumen yang dipakai adalah lembar observasi frekuensi penggunaan kata non santun.

Selanjutnya untuk kualitas pembelajaran dilakukan pengamatan aktivitas guru dalam google classroom. Instrument observasi menggunakan lembar observasi kualitas pembelajaran - Data yang diperoleh dari aspek frekuensi penggunaan kata non santun dan aspek kualitas pembelajaran,selanjutnya disajikan dalam bentuk grafik untuk memperjelas perubahan kondisinya selama periode Bulan September, Oktober dan Nopember 2020.

\section{HASIL DAN PEMBAHASAN}

Terkait dengan aspek frekuensi penggunaan kata non santun yang ditemukan di wa grup kelas IX-A didapatkan data sebagai berikut:

Tabel 1.Frekuensi penggunaan Kata Non santun di Wa Grup Kelas IX-A Bulan September, Oktober, Nopember 2020 


\begin{tabular}{|l|l|l|l|l|l|l|l|}
\hline Bulan & \multicolumn{5}{|c|}{ Frekuensi Kata Non Santun } & $\begin{array}{l}\text { Juml } \\
\text { ah }\end{array}$ & Rerata \\
\cline { 2 - 8 } & Pekan 1 & Pekan 2 & Pekan 3 & Pekan 4 & Pekan 5 & & \\
\hline $\begin{array}{l}\text { Septe } \\
\text { mber }\end{array}$ & 0 & 2 & 10 & 6 & 15 & 33 & $8 /$ minggu \\
\hline $\begin{array}{l}\text { Oktob } \\
\text { er }\end{array}$ & 6 & 10 & 2 & 5 & 0 & 23 & $4 /$ minggu \\
\hline $\begin{array}{l}\text { Nove } \\
\text { mber }\end{array}$ & 1 & 3 & - & 3 & - & 7 & $1 /$ minggu \\
\hline
\end{tabular}

Berdasarkan tabel di atas diketahui bahwa penggunaan kata non santun di wa grup setiap bulannya selalu ditemukan.Pada bulan September terdapat 33 kali penggunaan.Pada bulan Oktober terdeteksi 23 kali penggunaan kata non santun.Dan pada bulan Nopember ditemukan 7 kali penggunaan kata non santun.

Tindakan yang dilakukan guru pada saat menemui siswa menggunakan kata non santun di wa grup kelas IX-A ada dua tahap ; tahap pertama menegur secara halus,kedua langsung menegur dengan mengingatkan "pakai kata-kata santun" .Harus diakui bahwa tindakan tersebut tidak total menghilangkan penggunaan kata non santun namun sesuai data yang diperoleh menunjukkan tindakan guru baru mencapai hasil menurunkan frekuensi penggunaan kata non santun di wa grup.

Penurunan frekuensi penggunaan kata non santun pada bulan September ,Oktober dan Nopember 2020 dapat digambarkan dalam grafik berikut ini.

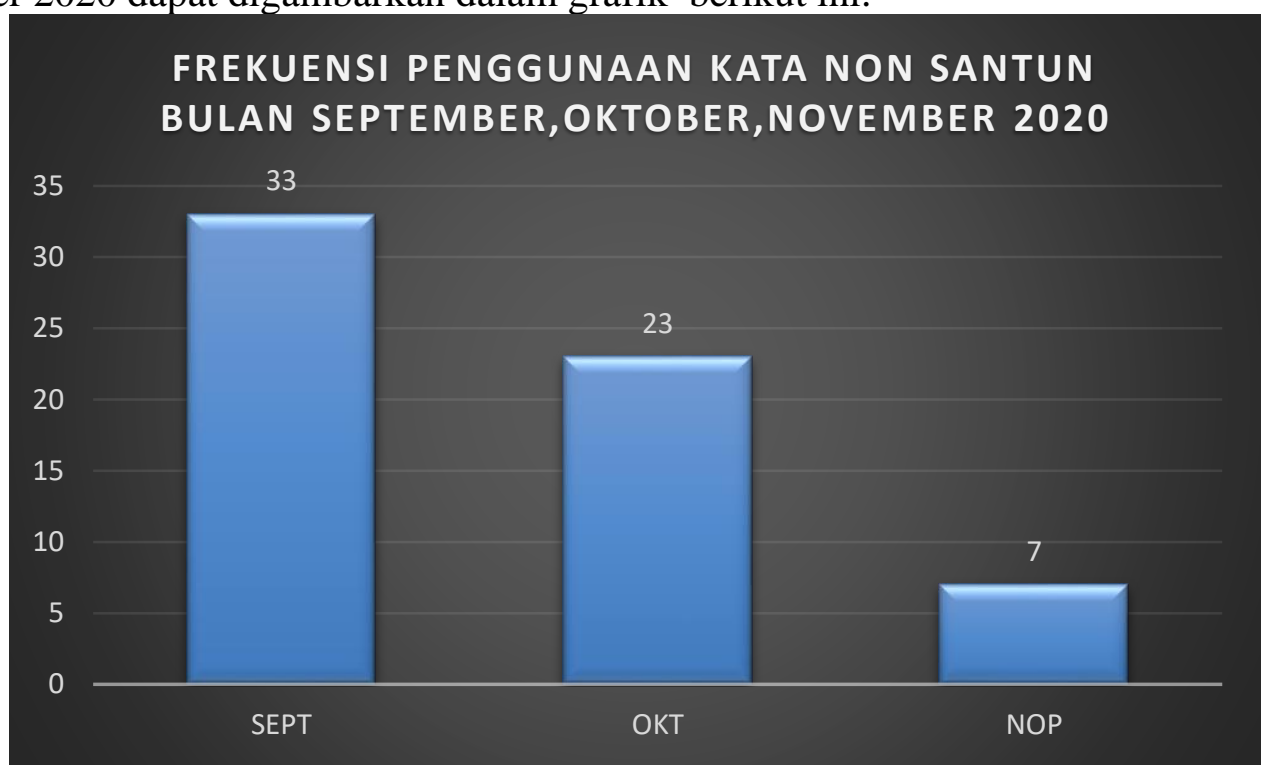

\section{Gambar 1. Penggunaan Kata Non Santun pada bulan September, Oktober dan Nopember 2020}

Terkait dengan aspek kualitas pembelajaran ditemukan capaian skor hasil observasi pembelajaran bulan September,Oktober dan Nopember. Hasil pengamatan bulan September mencapai skor 67 dengan kriteria baik. Aspek yang perlu diperbaiki di kegiatan awal adalah penyampaian protocol covid 19 , penyampaian SK/KD, penyampaian tujuan pembelajaran yang ingin dicapai.Sedangkan di kegiatan inti aspek penyiapan video materi pembelajaran , penyiapan link soal tugas,penyiapan link cadangan ,penggunaan wa untuk sarana pengiriman tugas kepada siswa masih perlu diperbaiki.Sementara untuk kegiatan penutup , aspek yang perlu diperbaiki adalah terkait pemberian tugas kuis,pemberian arahan doa akhir belajar ,pemberian umpan balik,pemberian penguatan kepada siswa cepat dalam merespon,proses rekapitulasi respon siswa dan proses klasifikasi respon siswa.

Hasil pengamatan pelaksanaan pembelajaran pada tanggal 13 Oktober 2020 dengan materi hakikat dan teori kedaulatan menghasilkan skor 75 dengan kriteria pembelajaran baik.Aspek yang masih perlu diperbaiki dalam tahap awal yaitu aspek penyampaian protocol 
covid 19.Sementara dalam tahap kegiatan inti yang perlu diperbaiki adalah penggunakan layanan wa sebagai sarana pengiriman tugas.

Hasil pengamatan terhadap pelaksanaan pembelajaran yang dilaksanakan pada tanggal 10 november 2020 dengan materi lembaga yudikatif Indonesia menghasilkan skor yang menggembirakan sebesar 88 dengan kriteria sangat baik. Nilai 4 diperoleh pada kegiatan awal khususnya indikator guru menyampaikan $\mathrm{KD}$ /pokok materi, guru menyampaikan tujuan pembelajaran,guru melampirkan video motivasi( indikator 4,5,6). Selain itu juga pada kegiatan inti indikator : guru menyiapkan video materi pembelajaran .guru menjalin komunikasi dengan siswa, guru menyiapkan link soal kuis,guru menyiapkan link soal pengganti (indikator nomor $7,11,12,13$ ), selanjutnya pada tahap penutup skor 4 diraih di indikator nomor 20" guru mengklasifikasi respon siswa secara klasikal ". Peningkatan skor kualitas pembelajaran tersebut apabila disajikan dalam bentuk grafik dapat dilihat pada grafik batang berikut ini.

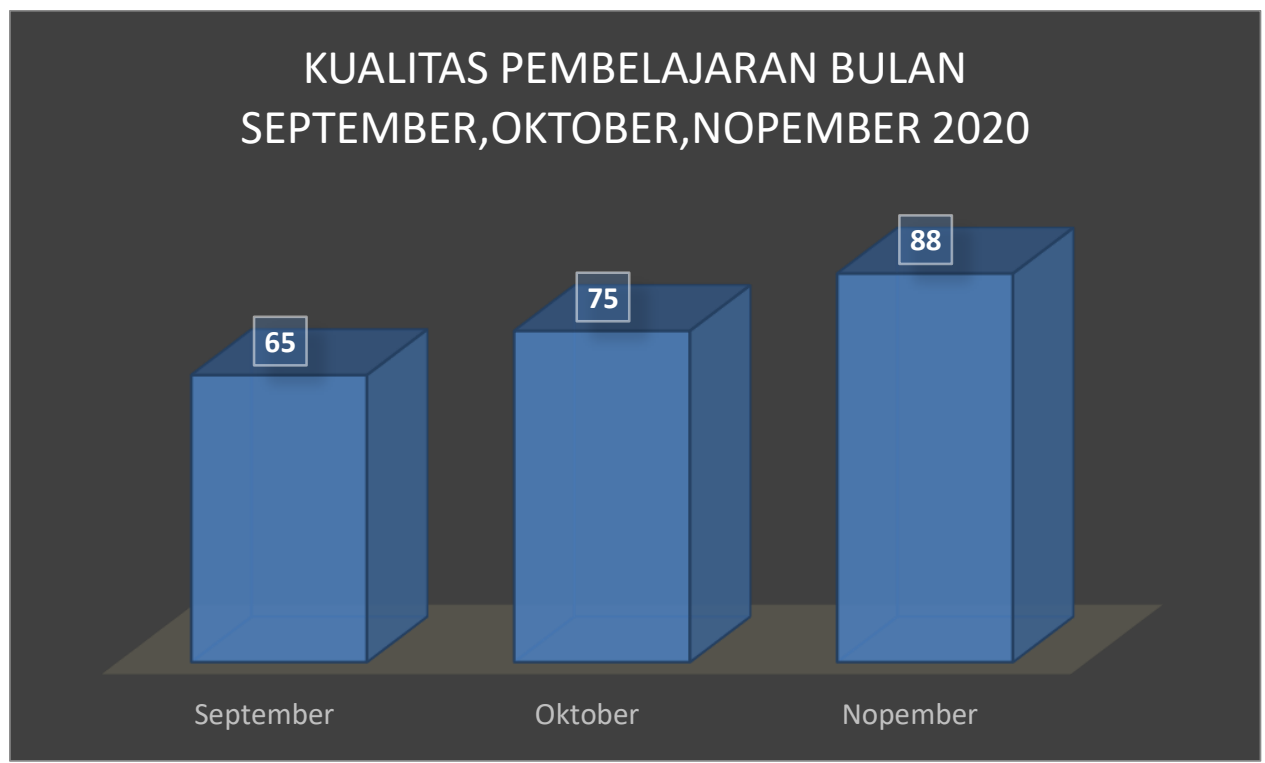

Gambar 2. Kualitas Pembelajaran Bulan September, Oktober, Nopember 2020

Tanggapan siswa terhadap video motivasi yang ditayangkan terangkum dalam hasil wawancara siswa.Wawancara dilaksanakan pada hari Jumat 13 November 2020. Responden dipilih acak dengan kriteria mewakili perolehan skor pengetahuan tinggi, sedang dan rendah.

1) Responden 1

Video motivasi bisa diterima dan tidak mengganggu jalannya pembelajaran di classroom.Saya jarang melihatnya karena yang saya pentingkan adalah penyelesaian tugas. Untuk video yang saya lihat saya bisa mengambil pesan baiknya.Saya mengharapkan penyampaian materi bisa lebih diperjelas.

2) Responden 2

Video motivasi tidak mengganggu proses pembelajaran Saya bisa melihat tayangan video merry Riana tapi jarang karena sinyal di daerah saya lemot.Saya bisa mengambil nasihat baik dari video Merry Riana Saran saya penyampaian materi PPKn bisa diperjelas lewat diterangkan langsung oleh guru dengan tatap muka. PJJ kali ini berhasil memenuhi HP saya namun isi kepala saya nyaris tidak ada.

3) Responden 3

Video Motivasi bisa diterima sebagai pendahuluan dalam forum class room. Saya bisa menonton video Motivasi setiap pembelajaran PPKn Saya bisa mengambil nilai moral baik dari video motivasi yang ditayangkan.Saya merasa format pembelajaran yang ada sudah bisa saya ikuti secara runtut.

4) Responden 4 


\section{EDUTECH : Jurnal Inovasi Pendidikan Berbantuan Teknologi Vol. 1 No. 2 Agustus 2021, e-ISSN : 2797-0140 | p-ISSN : 2797-0590}

Video motivasi bisa saya terima sebagai bagian dari forum pendahuluan di google class room. Saya bisa menonton video motivasi yang disajikan. Saya bisa mengambil nilai positif dari video motivasi yang ditayangkan. Saya mengharapkan pembelajaran tatap muka segera dilaksanakan agar lebih nyaman.

5) Video motivasi bisa menjadi bagian dari pendahuluan belajar di classroom.Saya jarang nonton video motivasi Merry Riana. Saya bisa mengambil nilai baik dari video motivasi berjudul "aku tidak sempurna" (Video terakhir dalam pembelajaran terakhir di smt gasal). Saya merindukan pembelajaran tatap muka.

Sehubungan dengan tugas menyaksikan vimot, responden terbagi dalam dua kelompok.Kelompok yang rutin menyaksikan vimot dan kelompok yang jarang menyaksikan vimot. Meskipun demikian semua responden sepakat bahwa mereka bisa mengambil pesan positif dari vimot.Dengan demikian adanya vimot bisa mendukung penguatan karakter di masa pandemik covid 19. Akibat positif dari kegiatan best practice ini ada dua hal.Pertama bagi guru mendapat pengalaman memanfaatkan video motivasi dalam pembelajaran jarak jauh.Kedua bagi siswa memperoleh pengalaman langsung untuk menyaksikan video motivasi sebagai tontonan yang mengandung tuntunan di mana selain bisa menyaksikan tayangan yang menghibur juga bisa menyimak nilai-nilai karakter dari tayangan yang disajikan.

Selain dampak positif tersebut ternyata masih ditemukan masalah yang timbul pada saat pelaksanaan best practice yang dilaksanakan. Antara lain: Pertama masih ditemukan siswa yang tidak tepat waktu mengumpulkan respon tugas siswa,Kedua masih ada siswa yang terkendala sinyal dan quota internet. Ketiga ada peserta didik yang tidak bisa mengakses google class room. Keempat masih ada peserta didik yang mendapat nilai di bawah kriteria ketuntasan minimal sekolah .

Cara mengatasi masalah tersebut dengan cara sebagai berikut:

1. memberi kesempatan penambahan waktu pengumpulan respon dan mengumumkan di wa grup nama - nama siswa yang perlu melengkapi pengiriman tugas.

2. mengusahakan agar siswa tersebut mendapat bantuan quota pelajar dari kemdikbud atau pihak lain

3. memberikan tugas kepada siswa lewat watschap dan siswa diijinkan mengirim respon tugas secara pribadi ke no wa guru (japri)

4. memberikan tugas pengganti kepada siswa yang kemampuannya di bawah rata- rata.

Merujuk penelitian konseptual dari Restu Dwi Arianto terkait implementasi pendidikan karakter dalam pembelajaran online, ada 3 faktor yang mempengaruhi keberhasilan pembelajaran daring. Pertama desain kursus, kedua motivasi pembelajar dan ketiga pengelolaan waktu. Desain kursus disarankan menggunakan modul yang dilengkapi tujuan pembelajaran, indikator karakter yang harus di capai, instrument pengukuran tiap pertemuan, asesmen penilaian akhir pembelajaran, refleksi kegiatan pembelajaran. Kursus yang dilakukan dapat dilakukan dengan menggunakan sinkronus dan asinkronus sesuai prinsip blended learning.

Motivasi dalam pembelajaran online akan dipengaruhi oleh motivasi intrinsik dan ekstrinsik. Dalam pembelajaran bermuatan karakter perlu ditanamkan konsep pembelajaran sepanjang hayat. Siswa harus diarahkan untuk nyaman belajar dimanapun dan kapanpun. Pada masa Pandemi COVID-19 siswa harus menerima kenyataan bahwa proses kegiatan pembelajaran dilakukan dirumah (School From Home). Guru dapat dapat membuat konten pembelajaran online yang menarik bagi siswa. Materi diusahakan tidak difokuskan pada interaksi online secara monoton. Kegiatan pembelajaran dapat divariasikan dengan kegiatan tugas mandiri yang mampu mengasah karakter siswa.

Pengelolaan waktu belajar selama Pandemi COVID-19 dapat dilakukan sesuai jadwal pembelajaran. Terkait dengan ini ada tiga kegiatan yang harus dilakukan guru.Pertama :guru menentukan indikator karakter yang ingin dicapai dalam pembelajaran online.Kedua: guru harus memperhatikan durasi ideal siswa antusias mengikuti ppembelajaran online. Ketiga: 
guru harus merancang kegiatan bermuatan karakter yang harus dilakukan siswa seusai mengikuti pembelajaran online.

Masukan lain untuk penguatan pendidikan karakter selama pandemi,menurut Takhroji Aji yang mengutip pendapat Ki Hajar Dewantara adalah hendaknya : "Setiap orang menjadi guru,setiap rumah menjadi sekolah".pernyataan ini mengandung makna bahwa pendidikan karakter harus menjalin kolaborasi antara pihak sekolah dan keluarga.Sinergi yang serasi antara keluarga dan sekolah akan memantapkan penguatan pendidikan karakter siswa di masa pandemi.

\section{KESIMPULAN}

Kesimpulan yang bisa diambil dari pelaksanaan best praktis ini adalah sbb:

1. Video motivasi dalam proses pembelajaran dapat menjadi media penguatan karakter siswa selama pembelajaran jarak jauh sehingga muncul kecenderungan semakin menurunnya penggunaan kata non santun dalam komunikasi wa grup kelas IX-A.

2. Menyisipkan video motivasi dalam pembelajaran tidak mengganggu proses pembelajaran yang berlangsung, bahkan berpengaruh positif pada peningkatan kualitas pembelajaran dalam kriteria sangat baik.

\section{DAFTAR PUSTAKA}

A, Restu Dwi,. Andrianie, Santi,. Hanggara, Guruh Sukma. (2020). Implementasi Pendidikan Karakter di masa Pandemi Covid-19:Tantangan dan Kontribusi, Universitas Nusantara PGRI Kediri restudwiariyanto@unpkediri.ac.id,diakses $4 \quad$ Agustus 2021:https://fip.unesa.ac.id/fipppti/public/proceeding/index.php/webinar 2020/article/view/122/92

Margareta Widiyasanti, Yulia Ayriza. (2018). Pengembangan Media Video Animasi Untuk Meningkatkan Motivasi Belajar Dan Karakter Tanggung Jawab Siswa Kelas V Sekolah Dasar Gugus 02 Kecamatan Srandakan:diakses 21 Juni 2021: https://journal.uny.ac.id/index.php/jpka/article/view/21489)

Nurhayati. (2019). Efektifitas Penggunaan Media Sosial (Whatsapp) dalam Penyampaian Pesan Dakwah Terhadap Kalangan Remaja Di Desa Seritanjung, Fakultas Agama Islam Universitas Muhammadiyah Palembang , diakses 17 Juni 2021: http://repository.umpalembang.ac.id/id/eprint/6108/1/61

Ricu Sidiq. (2021). Pemanfaatan Whatsapp Group dalam Pengimplementasian Nilai-Nilai Karakter Pancasila Pada Era Disrupsi,diakses 21 juni 2021: https://jurnal.unimed.ac.id/2012/index.php/ph/article/viewFile/16304/12673

Sadiman, A, dkk. (2010). Media Pendidikan. Jakarta: Rajawali Pers

Takhroji, Aji. (2020). Pendidikan Karakter di Masa Pandemi Tanggungjawab Siapa, diakses 5 Agustus 2021 :https://bdkjakarta.kemenag.go.id/berita/pendidikan-karakter-di-masapandemi-menjadi-tanggung-jawab-siapa

Widya, Ari Kusumadani. (2017). Keefektifan Layanan Informasi Menggunakan Video Motivasi Untuk Meningkatkan Motivasi Belajar Siswa Di SD Negeri Sendangmulyo 04 Semarang ,diakses 6 Agustus 2021: http://lib.unnes.ac.id/29834/1/1301412042 